\title{
Analisis Kinerja Keuangan Sektor Manufacture dengan Multiple Discriminant Analysis Bankcruptcy Model di Bursa Efek Indonesia Periode 2014 - 2017
}

\author{
${ }^{1}$ Yunan Surono, ${ }^{2}$ Sindy Dwiroro Pangestu \\ ${ }^{1}$ Dosen Fakultas Ekonomi, Universitas Batanghari Jambi, Indonesia. \\ ${ }^{2}$ Mahasiswa Magister Manajemen Universitas Batanghari Jambi, Indonesia.
}

\begin{abstract}
This research aims to prove the financial performance of Manufacture sector with Multiple Discriminant Analysis Bankruptcy Model when measured using the Altman's Z-score first model, Altman's Z-score revision and Altman's Z-score modifications, Springate model and Zmiejewski model as well as to get the stocks that have the best performance based on the model. In this research the population used is the stock sector manufacturing group on the Indonesia Stock Exchange in the year 2014 - 2017 as many as 166 issuers manufacture. This research sample is the manufacture sector company, which provides complete data, and has a total asset of positive value and fluctuates as many as 22 companies. This form of research is an explolanatoris research (explanatory Research). The results showed, that based on the first Altman's Z-score model, in 2014 the company's performance in a healthy or not bankrupt category was 31.82\%, while the company had a gray performance of $22.73 \%$, as for The company's performance with the category broke by $45.45 \%$. In 2015 the company's performance with a healthy category of 27,27,82\%, a company that had a gray performance of 27.27\%, the company's performance of the category went bankrupt by 45.45\%. In 2016 the company's performance with a healthy category of 22, 73, 82\%, the company had a gray performance of $36.36 \%$, as for the performance of the company with the category bankrupt by $36.36 \%$. In 2017 the company's performance with a category of $40.91 \%$, the company has a gray performance of $22.73 \%$, as for the performance of the company with the category bankrupt by $36.36 \%$. Based on the model Altman Z-Score revision can be concluded that in 2014 the company's performance with a healthy category of $31.82 \%$, a company that has a gray performance of 54.55\%, as for the performance of the company with the category bankrupt 13.64\%. Year 2015 the performance of the company with a healthy category of 27.27\%, the company has a gray performance of $54.55 \%$, the company with the category went bankrupt by $18.18 \%$. Year 2016 the company's performance with a healthy category of $45.45 \%$, while the company has a gray performance of $36.36 \%$, the company with the category went bankrupt by 18.18\%. Year 2017 the performance of the company with a healthy category of 50.00\%, the company that has a gray performance of $31.82 \%$, the performance of the company with the category bankrupt by $18.18 \%$. Based on the model of Altman Z-score modification can be concluded, namely in 2014 the performance of the company with a healthy category of $72.73 \%$, the company that has a gray performance of $22.73 \%$, as for the performance of the company with the category bankrupt of 4.55\%. In 2015 the company's performance with a healthy category of 72.73\%, while the company had a gray performance of $18.18 \%$, as for the company's performance in the category went bankrupt by 9.09\%. In 2016 the company's performance with a healthy category of $77.27 \%$, the company had a gray performance of $13.64 \%$, the company's performance in the category went bankrupt by 18.18\%. In 2017 the company's performance with a healthy category of $81.82 \%$, while the company had a gray performance of $13.64 \%$, as for the company's performance in the category went bankrupt by $4.55 \%$. Based on Springate model can be concluded, namely in 2014 the performance of the company with a healthy category of 59.09\%, while companies that have a gray performance is not there, as for the performance of the company with the category bankrupt by 40.91\%. In 2015 the company's performance with a healthy category of 50.00\%, while companies that had a gray performance did not exist, the performance of the company with the category went bankrupt by 50.00\%. In 2016 the company's performance with a healthy category of 59.09\%, while companies that have a gray performance does not exist, as for the performance of the company with the category bankrupt by $40.91 \%$. In 2017 the company's performance with a healthy category of $63.64 \%$, while companies that have a gray performance does not exist, as for the performance of the company with the category bankrupt by 36.36\%. Based on Zmiejewski model can be concluded, in 2014 to 2017 the performance of companies with a healthy or not bankrupt category is $100 \%$, while companies that have a gray performance does not exist, as for the performance of the company with Bankruptcy category does not exist. Stocks that have the best performance based on each multiple discriminant analysis bankruptcy models respectively, namely INTP, CEKA, MERK, GGRM, LMSH, CPIN, MLBI, IKBI, TRIS UNIC and INDF, who have never experienced bankruptcy or in financial distress.
\end{abstract}

Keywords : Multiple Discriminant Analysis Bankruptcy Model, Altman Z-Score Model, Altman Model Z-Score Revision, Model Altman Z-Score Modification, Springate Model, Zmiejewski Model.

\section{PENDAHULUAN}

Investasi di pasar modal, investor harus memiliki data yang komfrehensif tentang apa yang dijadikan objek investasi, sekaligus pengetahuan dan serangkaian kemungkinan keputusan yang diambil dengan mempertimbangkan risiko yang kecil. Indikator ekonomi yang digunakan untuk mengukur kinerja dalam bisnis dapat dilihat dari beberapa aspek, penggunaan indikator sebagai alat ukur dari suatu variabel sangat diperlukan, sebagai upaya untuk memudahkan dalam memahami maknanya. Indikator tersebut harus mampu 
Yunan Surono dan Sindy Dwiroro Pangestu, Analisis Kinerja Keuangan Sektor Manufacture dengan Multiple Discriminant Analysis Bankcruptcy Model di Bursa Efek Indonesia Periode 2014 - 2017

merepresentasikan variabel yang akan diukur secara tepat, sehingga secara ilmiah dapat diterima dan dipertanggungjawabkan kebenarannya sebagai indikator yang tepat untuk mengukur variabel. Indikator perusahaan memiliki kinerja yang baik dapat dilihat dari kinerja keuangannya. Kinerja keuangan tergambar secara jelas dalam laporan keuangan. Laporan keuangan yang diterbitkan oleh perusahaan merupakan salah satu sumber informasi mengenai posisi keuangan perusahaan, kinerja serta perubahan posisi keuangan yang bermanfaat untuk pengambilan keputusan yang tepat sehingga diperlukan alat analisis yang menghubungkan beberapa rasio sekaligus untuk menilai kondisi keuangan perusahaan dan diharapkan mampu meningkatkan nilai perusahaan. Tujuan utama perusahaan adalah meningkatkan nilai perusahaan melalui peningkatan kemakmuran pemilik atau pemegang saham. Nilai perusahaan dapat dinilai melalui rasio rasio keuangan seperti likuiditas, profitabilitas, aktifitas, leverage, kebijakan deviden, rasio pasar dan berbagai model lainnya. Rasio-rasio tersebut dapat menjadi indikasi bagi manajemen mengenai penilaian investor terhadap kinerja manajemen dimasa lalu dan prospeknya dimasa yang kan datang. Nilai perusahaan pada dasarnya merupakan gambaran kinerja perusahaan yang terefleksikan pada harga saham yang ada dipasar, karena harga pasar saham mencerminkan penilaian investor atas keseluruhan ekuitas yang dimiliki, sehingga nilai perusahaan merupakan nilai pasar.

Nilai perusahaan dapat dicapai dengan maksimum jika para pemegang saham menyerahkan urusan pengelolaan perusahaan pada orang orang yang berkompeten pada bidangnya seperti manajer atau komisaris. Selain variabel yang telah disebutkan diatas, maka perlu juga bagi investor untuk memahami pentingnya potensi dari kegagalan investasi yang sering dikenal sebagai risiko. Variabel dari model ini diambil dari neraca dan laporan laba/rugi perusahaan, seperti yang ada pada model multiple discriminant analysis, yang sering di jadikan sebagai bahan dan acuan bagi para peneliti, akademisi maupun para analis untuk melihat potensi kebangkrutan bagi suatu perusahaan. Edward I. Altman (1968), melakukan proses multiple discriminant analysis. Analisa diskriminan tersebut merupakan suatu analisis yang mengidentifikasikan beberapa macam rasio keuangan yang dirasakan memiliki nilai terpenting dalam mempengaruhi suatu kinerja tertentu maupun suatu keadaan, dan mengembangkannya ke dalam suatu model dengan maksud guna memudahkan dalam menarik kesimpulan dari suatu keadaaan. Analisis diskriminan ini kemudian menghasilkan beberapa pengelompokan yang bersifat mendasarkan teori pada kenyataan yang sebenarnya.

Multiple discriminant analysis ini diyakini akan mampu melihat kondisi keuangan perusahaan secara baik, sehingga dapat di jadikan sebagai antisipasi sedini mungkin (signal early warning system) terhadap kinerja dan kesehatan keuangan perusahaan yang dipengaruhi oleh beberapa indikator-indikator yang mampu menggambarkan kegagalan keuangan perusahaan. Altman memilih dan mengelompokkan beberapa indikator yang paling penting sebagai alat ukur untuk menilai kinerja keuangan perusahaan guna menilai potensi kesulitan keuangan (financial distress) yang di kenal dengan Altman's Z-score. Analisis kebangkrutan dilakukan untuk memperoleh peringatan awal kebangkrutan (tanda-tanda awal kebangkrutan). Semakin awal tanda-tanda kebangkrutan tersebut, semakin baik bagi pihak-pihak manajemen bisa melakukan perbaikan-perbaikan. Kesulitan keuangan menunjukkan adanya masalah likuiditas yang parah yang tidak dapat dipecahkan tanpa melalui penjadwalan kembali secara besar-besaran terhadap operasi dan struktur perusahaan. Altman's Z-score merupakan indikator untuk mengukur potensi kebangkrutan suatu perusahaan. Nilai Z-score diperoleh 5 unsur rasio; working capital to total assets, retairned earning to total assets, earning before interest and tax to total assets, market value to book value of total debt, and total revenue to total assets. Rasio-rasio tersebut menggambarkan rasio dari kemampuan manajemen di dalam mengelola aktiva perusahaan, sehingga Altman's Z-score dapat juga digunakan untuk mengukur kinerja perusahaan, yaitu dari sisi potensi kebangkrutan suatu perusahaan. Model ini dianggap tidak rumit, karena menggabungkan lima rasio keuangan yang bersumber dari informasi laporan akuntansi dan nilai ekuitas yang menggambarkan pengukuran secara obyektif dari kesehatan keuangan perusahaan, model ini dikenal dengan model Altman Zscore Pertama.

Altman kemudian mengembangkan model alternatif dengan menggantikan variabel X4 (Nilai pasar saham preferen dan biasa/nilai buku total). Revisi yang dilakukannya merupakan penyesuaian agar model prediksi kebangkrutan ini tidak hanya untuk perusahaan manufaktur yang go public melainkan juga dapat diterapkan untuk perusahaan sektor swasta sehingga dikenal dengan model Altman Revisi (Revised Model). Dengan demikian model tersebut dipakai baik untuk perusahaan yang go public maupun yang tidak go 
Yunan Surono dan Sindy Dwiroro Pangestu, Analisis Kinerja Keuangan Sektor Manufacture dengan Multiple Discriminant Analysis Bankcruptcy Model di Bursa Efek Indonesia Periode 2014 - 2017

public. Masalah lain yang perlu dipertimbangkan adalah banyak perusahaan yang tidak go public, dan dengan demikian tidak mempunyai nilai pasar. Untuk beberapa negara seperti Indonesia, perusahaan yang tidak go public memiliki jumlah yang cukup besar dari keseluruhan perusahaan yang ada. Altman kemudian memodifikasi modelnya agar dapat diterapkan pada semua perusahaan, seperti manufaktur, non manufaktur, dan perusahaan penerbit obligasi yang ada pada negara berkembang (emerging market) yang dikenal dengan Model Modifikasi (Modified Model). Dalam Z-score modifikasi ini Altman mengeliminasi variable X5 (sales/total asset.), hal tersebut dilakukan karena rasio ini sangat bervariatif pada industri dengan ukuran asset yang nilainya berbeda-beda.

Metode Springate merupakan model yang dikembangkan oleh Gordon L.V. Springate pada tahun 1978. Springate menggunakan metode yang sama dengan Altman yakni menggunakan multiple discriminant analysis. Springate memilih 4 rasio dari 19 rasio keuangan yang populer sehingga dapat membedakan perusahaan yang berada dalam zona bangkrut atau zona aman. Dalam model Springate jika Z > 0,862 maka perusahaan diklasifikasikan menjadi perusahaan sehat, jika skor $\mathrm{Z}<0,862$ maka perusahaan diklasifikasikan menjadi perusahaan yang potensi bangkrut. Zmijewski (1984) menggunakan analisis rasio yang mengukur kinerja, leverage, dan likuiditas suatu perusahaan untuk model prediksinya. Zmijewski menggunakan probit analisis yang diterapkan pada 40 perusahaan yang telah bangkrut dan 800 perusahaan yang masih bertahan saat itu. Model yang dikembangkan menggunakan variabel return on asset, leverage dan current ratio. Penelitian lanjutan tentang kebangkrutan suatu perusahaan yang menggunakan rasio keuangan untuk memprediksi kondisi financial distress suatu perusahaan antara lain dilakukan oleh Lau (1987); Doumpos \& Zouponidis (1999) serta Platt \& Platt (2002).

Platt \& Platt (2002), menggunakan rasio keuangan untuk mengukur financial distress dan menentukan rasio yang paling dominan untuk memprediksi financial distress. Platt \& Platt (1990) melakukan penelitian dengan membandingkan antara rasio keuangan yang tidak disesuaikan dengan rasio relatif industri. Hasil penelitian menunjukkan bahwa rasio yang tidak disesuaikan mempunyai tingkat klasifikasi yang lebih rendah dibanding jika menggunakan rasio relatif industri. Penelitian terdahulu juga dilakukan oleh Ayu Suci Ramdani dan Niki Lukviarman (2009), dengan menganalisis perbandingan analisis model kebangkrutan menggunakan model altman pertama, altman revisi dan altman modifikasi dengan ukuran dan umur perusahaan sebagai variabel penjelas pada perusahaan manufaktur di Bursa Efek Indonesia. Peneltian tersebut mencoba untuk menganalisis kinerja perusahaaan berdasarkan multiple discriminant analysis bankruptcy model, termasuk juga penelitian yang dilakukan oleh Kokyung (2014) dan Lazuardy (2016), yang menggunakan Z-score Altman, Springate dan Tobin's q.

Pada penelitian ini, penulis tertarik untuk meneliti data saham yang ada di Bursa Efek Indonesia, fokus pada perusahaan emiten yang bergerak di sektor manufacture. Adapun alasan yang mendasarinya adalah emiten sektor manufacture memegang peranan penting dalam menggerakkan sektor riil perekonomian suatu negara, mampu menyerap tenaga kerja dalam jumlah besar, serta menghasilkan produk massal yang digunakan oleh masyarakat, sehingga penting untuk mengikuti perkembangan dan perlu dimonitor terus bagaimanakah kinerja masing-masing emiten sektor manufacture yang berada terutama dilihat dari tekanan keuangannya (financial distress). Pada penelitian ini penulis tertarik untuk meneliti kelompok perusahaan manufaktur yang mempunyai total aktiva berfluktuasi, karena hal ini menggambarkan kondisi keuangan perusahaan yang tidak stabil, sehingga akan berdampak pada banyak aspek fundamental yang ada pada perusahan termasuk diantaranya besaran produksi, jumlah penjualan, besaran jumlah pendanaan, perolehan tingkat laba, kegiatan operasional dan kelangsungan hidup perusahaan dimasa yang akan datang. Situasi tersebut akan berpengaruh secara signifikan terhadap minat investor untuk melakukan investasi pada perusahaan sektor manufaktur tersebut.

\section{Landasan Teori \\ Kinerja Keuangan}

Kinerja keuangan merefleksikan kinerja fundamental perusahaan dan akan diukur dengan menggunakan data fundamental perusahaan, yaitu data yang berasal dari laporan keuangan perusahaan. Seorang investor dapat melakukan analisis fundamental secara "top-down" guna menilai prospek suatu perusahaan (Tandelilin, E., 2001). 
Yunan Surono dan Sindy Dwiroro Pangestu, Analisis Kinerja Keuangan Sektor Manufacture dengan Multiple Discriminant Analysis Bankcruptcy Model di Bursa Efek Indonesia Periode 2014 - 2017

\section{Potensi Kebangkrutan (Financial Distress).}

Plat dan Plat (2002), mendefinisikan bahwa financial distress adalah tahap penurunan kondisi keuangan yang dialami oleh suatu perusahaan, yang terjadi sebelum terjadinya kebangkrutan ataupun likuidasi. Financial distress dimulai dengan ketidakmampuan memenuhi kewajiban-kewajibannya, terutama kewajiban yang bersifat jangka pendek termasuk kewajiban likuiditas, dan juga termasuk kewajiban dalam kategori solvabilitas. Darmawan (2014), Financial Distress merupakan suatu situasi dimana aliran kas operasi sebuah perusahaan tidak cukup memuaskan kewajiban-kewajiban yang sekarang (seperti perdagangan kredit atau pengeluaran bunga) dan perusahaan dipaksa untuk melakukan tindakan korelatif.

\section{Model Altman Z-score Pertama}

Altman Z-score merupakan indikator untuk mengukur potensi kebangkrutan suatu perusahaan antara lain dengan 5 unsur rasio; working capital to total assets, retairned earning to total assets, earning before interest and tax to total assets, market value to book value of total debt, and total revenue to total assets. ZScore ditentukan dengan menggunakan rumus sebagai berikut; Ayu Suci R., (2009) :

$\mathrm{Z}$-Score $=1,2 \mathrm{X} 1+1,4 \mathrm{X} 2+3,3 \mathrm{X} 3+0,6 \mathrm{X} 4+0,999 \mathrm{X} 5$

Keterangan: X1 = Working Capital to Total Assets; X2 = Retained Earning to Total Assets; X3 = Earning Before Interest and Taxes (EBIT) to Total Assets; X4 = Market Value of Equity to Book Value of Total Liabilities; X5 = Sales to Total Assets

Altman mengkategorikan perusahaan yang mengalami kegagalan atau tidak pada masa mendatang ke dalam tiga kategori, yaitu:

- Jika nilai $Z<1,8$ maka termasuk perusahaan yang bangkrut.

- Jika nilai 1,8 $<\mathrm{Z}<2,99$ maka termasuk grey area (tidak dapat ditentukan apakah perusahaan sehat ataupun mengalami kebangkrutan).

- Jika nilai $Z>2,99$ maka termasuk perusahaan yang tidak bangkrut

\section{Model Altman Z-score Revisi}

Altman melakukan revisi sebagai upaya untuk melakukan penyesuaian agar model prediksi kebangkrutan ini tidak hanya untuk perusahaan manufaktur yang go publik, melainkan juga dapat diterapkan pada perusahaan sektor swasta. Masalah lain yang dipertimbangkan adalah banyak perusahaan yang tidak go public, sehingga tidak mempunyai nilai pasar. Untuk negara berkembang seperti Indonesia, perusahaan yang tidak go public banyak dijumpai dengan jumlah yang cukup besar didalamnya. Altman mengembangkan model alternatif dengan menggantikan variabel X4 (Nilai pasar saham preferen dan biasa/nilai buku total). Model Altman hasil revisi tahun 1983, persamaan yang diperoleh adalah sebagai berikut:

$Z^{\prime}=0,717 \mathrm{X} 1+0,847 \mathrm{X} 2+3,107 \mathrm{X} 3+0,420 \mathrm{X} 4+0,998 \mathrm{X} 5$

Keterangan: X1 = (Aktiva Lancar- Utang Lancar)/Total Aktiva; X2 = Laba yang Ditahan/Total Aset; X3 = Laba Sebelum Bunga dan Pajak/Total Aset; X4 = Nilai buku saham biasa dan preferen/Nilai buku total utang; X5 = Penjualan/Total Aset

Kategori perusahaan yang sehat dan bangkrut didasarkan pada nilai Z-Score metode Altman revisi yaitu:

- $\quad$ Nilai Z' $<1,23$ maka termasuk perusahaan yang bangkrut.

- Nilai $1,23<Z$ ' $<2,9$ maka termasuk grey area (tidak dapat ditentukan apakah perusahaan sehat atau mengalami kebangkrutan).

- $\quad$ Nilai Z' > 2,9 maka termasuk perusahaan tidak bangkrut.

\section{Altman Model Modifikasi}

Altman kemudian memodifikasi modelnya agar dapat diterapkan pada seluruh perusahaan, seperti manufaktur, non manufaktur, dan perusahaan penerbit obligasi di negara berkembang (emerging market). Dalam Z-score modifikasi ini, Altman mengeliminasi variable X5 (sales/total asset.), karena rasio ini sangat bervariatif pada industri dengan ukuran asset yang berbeda-beda. Persamaan Z-Score yang di modifikasi Altman (1995):

Z" $=6,56 \mathrm{X} 1+3,26 \mathrm{X} 2+6,72 \times 3+1,05 \mathrm{X} 4$

Keterangan: $\mathrm{Z} "=$ bankrupcy index; $\mathrm{X} 1=$ working capital/total asset $; \mathrm{X} 2$ = retained earnings $/$ total asset; $\mathrm{X} 3$ = earning before interest and taxes/total asset; $\mathrm{X} 4=$ book value of equity/book value of total debt 
Yunan Surono dan Sindy Dwiroro Pangestu, Analisis Kinerja Keuangan Sektor Manufacture dengan Multiple Discriminant Analysis Bankcruptcy Model di Bursa Efek Indonesia Periode 2014 - 2017

Kategori perusahaan yang sehat dan bangkrut didasarkan pada nilai Z-score model Altman modifikasi yaitu:

- Jika nilai Z" <1,1 maka termasuk perusahaan yang bangkrut.

- Jika nilai 1,1 $<$ Z" $<2,6$ maka termasuk grey area (tidak dapat ditentukan apakah perusahaan sehat ataupun mengalami kebangkrutan).

- Jika nilai Z"> 2,6 maka termasuk perusahaan yang tidak bangkrut.

\section{Springate Model}

Kokyung (2013), menyampaikan bahwa metode Springate ditemukan oleh Gordon L.V Springate pada tahun 1978, Springate menemukan terdapat 4 dari 19 rasio-rasio keuangan yang paling berkontribusi terhadap prediksi kebangkrutan perusahaan. Keempat rasio keuangan tersebut dikombinasikan dalam suatu formula yang bernama metode Springate. Springate menentukan batasan (standar) berupa nilai 0,862 untuk memprediksikan perusahaan berpotensi bangkrut atau berpotensi sebagai perusahaan yang sehat (tidak bangkrut). Metode Springate dirumuskan dalam suatu formula sebagai berikut:

$\mathrm{Z}=1,03 \mathrm{X} 1+3,07 \mathrm{X} 2+0,66 \mathrm{X} 3+0,4 \mathrm{X} 4$

Dimana: X1 = Working capital $/$ total assets; X2 = Net profit before interest and taxes $/$ total assets; $\mathrm{X} 3=$ Net profit before taxes / current liabilities; $\mathrm{X} 4$ = Sales / total assets

Model ini mempunyai standar dimana perusahaan yang mempunyai skor $Z>0,862$ diklasifikasikan sebagai perusahaan yang sehat, sedangkan perusahaan yang mempunyai skor $\mathrm{Z}<0,862$ diklasifikasikan sebagai perusahaan yang berpotensi bangkrut.

\section{Zmijewski Model}

Zmijewski (1984), melakukan penelitian menggunakan analisis rasio yang mengukur kinerja perusahaan berdasarkan leverage dan likuiditas dalam memprediksi tekanan keuangan (financial distress), Penelitian yang dilakukan Zmijewski terhadap 40 perusahaan yang telah bangkrut dari 800 perusahaan yang ada pada saat dilakukan penelitian. Adapun model yang berhasil dikembangkan dengan formula berikut; $\mathrm{X}=-4,3-4,5 . \mathrm{X} 1+5,7 . \mathrm{X} 2-0,004 . \mathrm{X} 3$

Dimana: $\mathrm{X} 1=$ Return On Assets $(\mathrm{ROA}) ; \mathrm{X} 2=$ Leverage (debt ratio); X3 = Likuiditas (current ratio).

Kriteria penilaian dari model Zmijewski ini yakni semakin besar nilai X, maka akan semakin besar kemungkinan / probabilitas perusahaan tersebut akan bangkrut, sehingga dalam menganalisis model ini dapat dikatakan bahwa jika bernilai negatif maka perusahaan tersebut tidak berpotensi bangkrut. Multiple discriminant analysis bankruptcy model, merupakan analisis yang mampu melihat hubungan rasio - rasio tertentu yang dapat mempengaruhi kinerja keuangan perusahaan, yakni mampu menghubungkan antara likuiditas, solvabilitas dan profitabilitas perusahaan dengan potensi kebangkrutan. Model multiple discriminant analysis ini dapat dipergunakan untuk seluruh perusahaan publik, pribadi, manufaktur ataupun perusahaan jasa dalam berbagai ukuran. Model - model ini diharapkan dapat digunakan di negara berkembang seperti Indonesia. Model multiple discriminant analysis ini, dapat digunakan untuk memantau kondisi keuangan perusahaan, sehingga diharapkan akan mampu membuat keputusan yang semakin baik dan lebih baik lagi, sehingga dapat di antisipasi sedini mungkin (early warning system) terhadap kinerja dan kesehatan keuangan perusahaan yang dipengaruhi oleh beberapa indikator-indikator kegagalan keuangan perusahaan. Perusahaan atau pihak manajemen, akan mampu melakukan perbaikan-perbaikan dengan cepat dan tepat untuk mengambil keputusan dan bermanfaat untuk menghindari tekanan keuangan.

\section{HASIL}

Hasil perhitungan dengan menggunakan multiple discriminant analysis bankruptcy model yakni model Altman's Z-score pertama, model Altman's Z-score revisi, model Altman's Z-score modifikasi, model Springate dan model Zmijewski. pada sektor manufacture yang terdaftar di Bursa Efek Indonesia, sebanyak 22 perusahaan emiten diperoleh sebagai berikut: 
Yunan Surono dan Sindy Dwiroro Pangestu, Analisis Kinerja Keuangan Sektor Manufacture dengan Multiple Discriminant Analysis Bankcruptcy Model di Bursa Efek Indonesia Periode 2014 - 2017

Tabel 1

Hasil Multiple Discriminant Analysis Bankruptcy Model

\begin{tabular}{|c|c|c|c|c|c|c|c|c|c|c|c|c|c|c|c|c|c|c|c|c|c|}
\hline \multicolumn{22}{|c|}{ ALAT ANALISIS } \\
\hline \multicolumn{6}{|c|}{ Altman Z-score model Pertama } & \multicolumn{4}{|c|}{ Altman Z-score modd Revisi } & \multicolumn{4}{|c|}{ Altman Z-score model Modifikasi } & \multicolumn{4}{|c|}{ Mbdel Springate } & \multicolumn{4}{|c|}{ Modd Zmiejewski } \\
\hline $\mathrm{N}_{0}$ & Emiten & 2014 & 2015 & 2016 & 2017 & 2014 & 2015 & 2016 & 2017 & 2014 & 2015 & 2016 & 2017 & 2014 & 2015 & 2016 & 2017 & 2014 & 2015 & 2016 & 2017 \\
\hline 1 & INTP & Sehat & Sehat & Sehat & Sehat & Sehat & Sehat & Sehat & Sehat & Sehat & Sehat & Sehat & Sehat & Sehat & Sehat & Sehat & Sehat & Sehat & Sehat & Sehat & Sehat \\
\hline 2 & CPIN & Sehat & Abu-abu & Sehat & Sehat & Abu-abu & Abu-abu & Sehat & Sehat & Sehat & Sehat & Sehat & Sehat & Sehat & Sehat & Sehat & Sehat & Sehat & Sehat & Sehat & Sehat \\
\hline 3 & TRIS & Sehat & Sehat & Abu-abu & Sehat & Abu-abu & Abu-abu & Abu-abu & Abu-abu & Sehat & Sehat & Sehat & Sehat & Sehat & Sehat & Sehat & Sehat & Sehat & Sehat & Sehat & Sehat \\
\hline 4 & CEKA & Sehat & Sehat & Sehat & Sehat & Sehat & Sehat & Sehat & Sehat & Sehat & Sehat & Sehat & Sehat & Sehat & Sehat & Sehat & Sehat & Sehat & Sehat & Sehat & Sehat \\
\hline 5 & MLBI & Sehat & Abu-abu & Sehat & Sehat & Sehat & Abu-abu & Sehat & Sehat & Abu-abu & Sehat & Sehat & Sehat & Sehat & Sehat & Sehat & Sehat & Sehat & Sehat & Sehat & Sehat \\
\hline 6 & GGRM & Sehat & Sehat & Sehat & Sehat & Abu-abu & Sehat & Sehat & Sehat & Sehat & Sehat & Sehat & Sehat & Sehat & Sehat & Sehat & Sehat & Sehat & Sehat & Sehat & Sehat \\
\hline 7 & MERK & Sehat & Sehat & Sehat & Sehat & Sehat & Sehat & Sehat & Sehat & Sehat & Sehat & Sehat & Sehat & Sehat & Sehat & Sehat & Sehat & Sehat & Sehat & Sehat & Sehat \\
\hline 8 & LMSH & Abu-abu & Sehat & Abu-abu & Sehat & Sehat & Sehat & Sehat & Sehat & Sehat & Sehat & $\begin{array}{l}\text { Sehat } \\
\end{array}$ & Sehat & Sehat & Sehat & Sehat & Sehat & Sehat & Sehat & Sehat & Sehat \\
\hline 9 & UNIC & Abu-abu & Abu-abu & Abu-abu & Abu-abu & Abu-abu & Abu-abu & Sehat & Sehat & Sehat & Sehat & Sehat & Sehat & Sehat & Sehat & Sehat & Sehat & Sehat & Sehat & Sehat & Sehat \\
\hline 10 & IMPC & Abu-abu & Abu-abu & Abu-abu & Bangkrut & Abu-abu & Abu-abu & Abu-abu & Sehat & Sehat & Sehat & Sehat & Sehat & Sehat & Sehat & Sehat & Sehat & Sehat & Sehat & Sehat & Sehat \\
\hline 11 & KDSI & Abu-abu & Abu-abu & Abu-abu & Abu-abu & Abu-abu & Abu-abu & Abu-abu & Abu-abu & Sehat & Abu-abu & Sehat & Sehat & Sehat & Bangkrut & Sehat & Sehat & Sehat & Sehat & Sehat & Sehat \\
\hline 12 & $\mathbb{K}$ KBI & Abu-abu & Abu-abu & Abu-abu & Abu-abu & Sehat & Sehat & Sehat & Sehat & Sehat & Sehat & Sehat & Sehat & Sehat & Sehat & Sehat & Sehat & Sehat & Sehat & Sehat & Sehat \\
\hline 13 & AKPI & Bangkrut & Bangkrut & Bangkrut & Bangkrut & Abu-abu & Bangknut & Bangkrut & Bangkrut & Abu-abu & Bangknut & Bangkrut & Bangkut & Bangkrut & Bangkrut & Bangkrut & Bangknut & Sehat & Sehat & Sehat & Sehat \\
\hline 14 & POL & Bangkrut & Bangkrut & Bangknut & Bangkrut & Abu-abu & Abu-abu & Abu-abu & Abu-abu & Abu-abu & Abu-abu & Abu-abu & Abu-1bu & Bangkrut & Bangkrut & Bangkrut & Bangknut & Sehat & Sehat & Sehat & Sehat \\
\hline 15 & TRST & Bangkrut & Bangknut & Bangkrut & Bangkrut & Abu-abu & Abu-abu & Abu-abu & Abu-abu & Sehat & Sehat & Sehat & Sehat & Bangknut & Bangkrut & Bangkrut & Bangkrut & Sehat & Sehat & Sehat & Sehat \\
\hline 16 & INKP & Bangkrut & Bangkrut & Bangkrut & Bangkrut & Bangkut & Bangknut & Bangkrut & Bangkrut & Abu-abu & Abu-abu & Abu-abu & Sehat & Bangkrut & Bangkrut & Bangkrut & Bangknut & Sehat & Sehat & Sehat & Sehat \\
\hline 17 & TKIM & Bangkrut & Bangknut & Bangkrut & Bangkrut & Bangkut & Bangkrut & Bangkrut & Bangknut & Abu-abu & Abu-abu & Abu-abu & Abu-1bu & Bangkut & Bangkrut & Bangkrut & Bangknut & Sehat & Sehat & Sehat & Sehat \\
\hline 18 & BRAM & Bangkrut & Bangkrut & Bangkrut & Bangkrut & Abu-abu & Abu-abu & Abu-abu & Abu-abu & Sehat & Sehat & Sehat & Sehat & Bangkrut & Bangkrut & Sehat & Sehat & Sehat & Sehat & Sehat & Sehat \\
\hline 19 & INDS & Bangkrut & Bangknut & Bangkut & Abu-abu & Sehat & Abu-abu & Sehat & Sehat & Sehat & Sehat & Sehat & Sehat & \begin{tabular}{|l|} 
Sehat \\
\end{tabular} & Bangkrut & \begin{tabular}{|l|} 
Bangkrut \\
\end{tabular} & Sehat & Sehat & Sehat & Sehat & Sehat \\
\hline 20 & STAR & Bangkrut & Bangknut & Abu-abu & Sehat & Abu-abu & $A b u-a b u$ & Abu-abu & Abu-abu & Sehat & Sehat & Sehat & Sehat & Bangkrut & Bangkrut & Bangkrut & Bangknut & Sehat & Sehat & Sehat & Sehat \\
\hline 21 & UNTT & Bangkrut & Bangkrut & Bangkrut & Bangkrut & Bangkrut & Bangkrut & Bangkrut & Bangkrut & Bamgkrut & Bangkrut & Bangkrut & Abu-1bu & Bangkrut & Bangkrut & Bangkrut & Bangkrut & Sehat & Sehat & Sehat & Sehat \\
\hline 22 & NDF & Bangkrut & Bangknut & Abu-abu & Abu-abu & $A b u-a b u$ & Abu-abu & Abu-abu & Sehat & \begin{tabular}{|l|} 
Sehat \\
\end{tabular} & \begin{tabular}{|l|} 
Sehat \\
\end{tabular} & Sehat & \begin{tabular}{|l|} 
Sehat \\
\end{tabular} & Bangknut & Bangkrut & Bangkrut & Bangkrut & Sehat & Sehat & Sehat & Sehat \\
\hline
\end{tabular}

Sumber: data olahan

Ringkasan keseluruhan kinerja keuangan sektor manufacture dengan multiple discriminant analysis bankruptcy model seperti pada tabel 2 berikut;

Tabel 2

Hasil Multiple Discriminant Analysis Bankruptcy Model

\begin{tabular}{|c|c|c|c|c|c|c|c|c|c|c|c|c|c|c|c|c|}
\hline & & \multicolumn{3}{|c|}{ AltmanZ-scorePertama } & \multicolumn{3}{|c|}{ Altman Z-score Revisi } & \multicolumn{3}{|c|}{ Altman Z-score Modifikasi } & \multicolumn{3}{|c|}{ Model Springate } & \multicolumn{3}{|c|}{ Model Zmiejenski } \\
\hline $\mathrm{N}_{0}$ & Tahun & Sehat & Abu-abu & Bangkrut & Sehat & Abutabu & Bangkrut & Sehat & Aburabu & Bangkru & Sehat & Abur-ab & Bangkrut & Sehat & Abur-abu & Bangkrut \\
\hline & 2014 & 31,82 & 2,73 & 45,45 & 31,82 & 54,5 & 13,64 & 72,73 & 2,7 & 4,5 & 59,0 & 0 & 40,91 & 100,00 & 0,00 & 0,00 \\
\hline 2 & 2015 & 2727 & 27,27 & 45,45 & 27,27 & 54,5 & 18,18 & 72,73 & 18,1 & 9,0 & 50,0 & 0,0 & 50,00 & 100,00 & 0,00 & 0,00 \\
\hline 3 & 2016 & 22,73 & 36,36 & 36,36 & 45,45 & 36,3 & 18,18 & 77,27 & 13,6 & 18,1 & 59,0 &, 0 & 40,91 & 100,00 & 0,00 & 0,00 \\
\hline 4 & 2017 & 40,91 & 22,7 & 36,36 & 50,00 & 31,8 & 18,18 & 81,82 & 13,6 & 4,5 & 63,6 & 0,0 & 36,36 & 100,00 & 0,00 & 0,00 \\
\hline
\end{tabular}

Sumber: data olahan

Kinerja keuangan sektor manufacture dengan multiple discriminant analysis bankruptcy model sebagai berikut;

a. Kinerja keuangan sektor manufacture dengan model Altman Z-score Pertama dapat dijelaskan, yakni pada tahun 2014 kinerja perusahaan dengan kategori sehat atau tidak bangkrut adalah sebesar 31,82\%, sedangkan perusahaan yang mempunyai kinerja abu-abu atau tidak dapat ditentukan apakah perusahaan sehat atau mengalami kebangkrutan adalah sebesar 22,73\%, adapun kinerja perusahaan dengan kategori bangkrut atau dalam tekanan keuangan (financial distress) adalah sebesar 45,45\%.

Pada tahun 2015 kinerja perusahaan dengan kategori sehat atau tidak bangkrut adalah sebesar 27,27,82\%, sedangkan perusahaan yang mempunyai kinerja abu-abu atau tidak dapat ditentukan apakah perusahaan sehat atau mengalami kebangkrutan adalah sebesar 27,27\%, adapun kinerja perusahaan dengan kategori bangkrut atau dalam tekanan keuangan (financial distress) adalah sebesar 45,45\%.

Pada tahun 2016 kinerja perusahaan dengan kategori sehat atau tidak bangkrut adalah sebesar 22,73,82\%, sedangkan perusahaan yang mempunyai kinerja abu-abu atau tidak dapat ditentukan apakah perusahaan sehat atau mengalami kebangkrutan adalah sebesar 36,36\%, adapun kinerja perusahaan dengan kategori bangkrut atau dalam tekanan keuangan (financial distress) adalah sebesar 36,36\%.

Pada tahun 2017 kinerja perusahaan dengan kategori sehat atau tidak bangkrut adalah sebesar 40,91\%, sedangkan perusahaan yang mempunyai kinerja abu-abu atau tidak dapat ditentukan apakah perusahaan 
Yunan Surono dan Sindy Dwiroro Pangestu, Analisis Kinerja Keuangan Sektor Manufacture dengan Multiple Discriminant Analysis Bankcruptcy Model di Bursa Efek Indonesia Periode 2014 - 2017

sehat atau mengalami kebangkrutan adalah sebesar 22,73\%, adapun kinerja perusahaan dengan kategori bangkrut atau dalam tekanan keuangan (financial distress) adalah sebesar 36,36\%.

b. Kinerja keuangan sektor manufacture dengan model Altman Z-score Revisi dapat dijelaskan, yakni pada tahun 2014 kinerja perusahaan dengan kategori sehat atau tidak bangkrut adalah sebesar 31,82\%, sedangkan perusahaan yang mempunyai kinerja abu-abu atau tidak dapat ditentukan apakah perusahaan sehat atau mengalami kebangkrutan adalah sebesar 54,55\%, adapun kinerja perusahaan dengan kategori bangkrut atau dalam tekanan keuangan (financial distress) adalah sebesar 13,64\%.

Pada tahun 2015 kinerja perusahaan dengan kategori sehat atau tidak bangkrut adalah sebesar 27,27\%, sedangkan perusahaan yang mempunyai kinerja abu-abu atau tidak dapat ditentukan apakah perusahaan sehat atau mengalami kebangkrutan adalah sebesar 54,55\%, adapun kinerja perusahaan dengan kategori bangkrut atau dalam tekanan keuangan (financial distress) adalah sebesar 18,18\%.

Pada tahun 2016 kinerja perusahaan dengan kategori sehat atau tidak bangkrut adalah sebesar 45,45\%, sedangkan perusahaan yang mempunyai kinerja abu-abu atau tidak dapat ditentukan apakah perusahaan sehat atau mengalami kebangkrutan adalah sebesar 36,36\%, adapun kinerja perusahaan dengan kategori bangkrut atau dalam tekanan keuangan (financial distress) adalah sebesar 18,18\%.

Pada tahun 2017 kinerja perusahaan dengan kategori sehat atau tidak bangkrut adalah sebesar 50,00\%, sedangkan perusahaan yang mempunyai kinerja abu-abu atau tidak dapat ditentukan apakah perusahaan sehat atau mengalami kebangkrutan adalah sebesar 31,82\%, adapun kinerja perusahaan dengan kategori bangkrut atau dalam tekanan keuangan (financial distress) adalah sebesar 18,18\%.

c. Kinerja keuangan sektor manufacture dengan model Altman Z-score Modifikasi dapat dijelaskan, yakni pada tahun 2014 kinerja perusahaan dengan kategori sehat atau tidak bangkrut adalah sebesar 72,73\%, sedangkan perusahaan yang mempunyai kinerja abu-abu atau tidak dapat ditentukan apakah perusahaan sehat atau mengalami kebangkrutan adalah sebesar 22,73\%, adapun kinerja perusahaan dengan kategori bangkrut atau dalam tekanan keuangan (financial distress) adalah sebesar 4,55\%.

Pada tahun 2015 kinerja perusahaan dengan kategori sehat atau tidak bangkrut adalah sebesar 72,73\%, sedangkan perusahaan yang mempunyai kinerja abu-abu atau tidak dapat ditentukan apakah perusahaan sehat atau mengalami kebangkrutan adalah sebesar 18,18\%, adapun kinerja perusahaan dengan kategori bangkrut atau dalam tekanan keuangan (financial distress) adalah sebesar 9,09\%.

Pada tahun 2016 kinerja perusahaan dengan kategori sehat atau tidak bangkrut adalah sebesar 77,27\%, sedangkan perusahaan yang mempunyai kinerja abu-abu atau tidak dapat ditentukan apakah perusahaan sehat atau mengalami kebangkrutan adalah sebesar 13,64\%, adapun kinerja perusahaan dengan kategori bangkrut atau dalam tekanan keuangan (financial distress) adalah sebesar 18,18\%.

Pada tahun 2017 kinerja perusahaan dengan kategori sehat atau tidak bangkrut adalah sebesar 81,82\%, sedangkan perusahaan yang mempunyai kinerja abu-abu atau tidak dapat ditentukan apakah perusahaan sehat atau mengalami kebangkrutan adalah sebesar 13,64\%, adapun kinerja perusahaan dengan kategori bangkrut atau dalam tekanan keuangan (financial distress) adalah sebesar 4,55\%.

d. Kinerja keuangan sektor manufacture dengan model Springate dapat dijelaskan, yakni pada tahun 2014 kinerja perusahaan dengan kategori sehat atau tidak bangkrut adalah sebesar 59,09\%, sedangkan perusahaan yang mempunyai kinerja abu-abu atau tidak ada, adapun kinerja perusahaan dengan kategori bangkrut atau dalam tekanan keuangan (financial distress) adalah sebesar 40,91\%.

Pada tahun 2015 kinerja perusahaan dengan kategori sehat atau tidak bangkrut adalah sebesar 50,00\%, sedangkan perusahaan yang mempunyai kinerja abu-abu atau tidak ada, adapun kinerja perusahaan dengan kategori bangkrut atau dalam tekanan keuangan (financial distress) adalah sebesar 50,00\%.

Pada tahun 2016 kinerja perusahaan dengan kategori sehat atau tidak bangkrut adalah sebesar 59,09\%, sedangkan perusahaan yang mempunyai kinerja abu-abu atau tidak ada, adapun kinerja perusahaan dengan kategori bangkrut atau dalam tekanan keuangan (financial distress) adalah sebesar 40,91\%.

Pada tahun 2017 kinerja perusahaan dengan kategori sehat atau tidak bangkrut adalah sebesar 63,64\%, sedangkan perusahaan yang mempunyai kinerja abu-abu atau tidak ada, adapun kinerja perusahaan dengan kategori bangkrut atau dalam tekanan keuangan (financial distress) adalah sebesar 36,36\%.

e. Kinerja keuangan sektor manufacture dengan model Zmiejewski dapat dijelaskan, yakni pada tahun 2014 sampai 2017 kinerja perusahaan dengan kategori sehat atau tidak bangkrut adalah sebesar 100\%, 
Yunan Surono dan Sindy Dwiroro Pangestu, Analisis Kinerja Keuangan Sektor Manufacture dengan Multiple Discriminant Analysis Bankcruptcy Model di Bursa Efek Indonesia Periode 2014 - 2017

sedangkan perusahaan yang mempunyai kinerja abu-abu tidak ada, adapun kinerja perusahaan dengan kategori bangkrut atau dalam tekanan keuangan (financial distress) tidak ada.

f. Saham - saham yang mempunyai kinerja paling baik berdasarkan masing-masing multiple discriminant analysis bankruptcy model secara berturut-turut yakni INTP, CEKA, MERK, GGRM, LMSH, CPIN, MLBI, IKBI, TRIS UNIC dan INDF, yang tidak pernah mengalami kebangkrutan atau dalam tekanan keuangan (financial distress).

\section{SIMPULAN}

Saham-saham yang mempunyai kinerja paling baik berdasarkan masing-masing multiple discriminant analysis bankruptcy model secara berturut-turut yakni INTP, CEKA, MERK, GGRM, LMSH, CPIN, MLBI, IKBI, TRIS UNIC dan INDF, yang tidak pernah mengalami kebangkrutan atau dalam tekanan keuangan (financial distress).

\section{DAFTAR PUSTAKA}

Altman, E.I. 1968, Financial Ratios, Discriminant Analysis and the Prediction of Corporate Bankruptcy. Journal of Finance, 23: 589-609.

Ayu Suci Ramdhani dan Niki Lukviarman, 2009, Perbandingan Analisis Model Kebangkrutan Menggunakan Model Altman Pertama, Altman Revisi Dan Altman Modifikasi Dengan Ukuran Dan Umur Perusahaan Sebagai Variabel Penjelas (Studi Pada Perusahaan Manufaktur Yang Terdaftar Di Bursa Efek Indonesia). Jurnal

Bambang Sudiyatno dan Elen Puspitasari 2010, Tobin,s q dan Altman's Z-score sebagai indikator pengukuran kinerja perusahaan. Jurnal

Brigham E, Houston J, 2001, Manajemen Keuangan, Buku 1, Edisi Kedelapan, Penerbit Airlangga,Jakarta.

Darmawan, Deni. 2014. Metode Penelitian Kuantitatif. Bandung : PT. Remaja Rosdakarya

Darsono dan Ashari, 2005, Pedoman Praktis Memahami Laporan Keuangan, Yogyakarta: ANDI

Doumpos, M. \& Zouponidis, C. 1999,. A Multicriteria Discrimination Method for Prediction of Financial Distress: The Case of Greece. Multinational Finance Journal, 3(2): 71-101.

Fatmawati, Mila 2012, Penggunaan the Zmijewski model, the Altman model dan Springate model sebagai prediktor delisting. Jurnal Keuangan dan Perbankan, Vol 16. No.1., Januari 2012. Hal 56-65.

Hanafi M. Mamduh \& Halim Abdul. 2016, Analisis Laporan Keuangan, Edisi ke-5, Yogyakarta:UPP STIM YKPN

Harahap, Sofyan Syafri, 2010, Analisis Kritis Atas Laporan Keuangan, Jakarta: PT. Raja Grafindo Persada,

Husnan S, 1994, Dasar-dasar Teori Portofolio dan Analisi Sekuritas, Edisi Kedua, Penerbit UPP-AMP YKPN, Yogyakarta.

Kokyung dan Siti Khairani 2013, Analisis Penggunaan Altman Z-score dan Springate untuk Mengetahui Potensi Kebangkrutan pada PT.Bakrie Telecom, STIE, MDP.

Lau, A.H. 1987, A Five State Financial Distress Prediction Model. Journal of Accounting Research, 25: 127138.

Lazuardy, M. Hikam 2016, Analisis Pengukuran Kinerja Keuangan Dengan Model Altman Z-Score dan Tobin's Q. Studi Kasus Pada Perusahaan Sektor Makanan Dan Minuman Di BEI Periode 2010 2014. Jurnal

Martin John B, Keown Arthur J, 1995, Dasar-dasar Manajemen Keuangan, Edisi Kelima, Jilid 1, Penerbit PT. Raja Grafindo Persad, Jakarta.

Peter dan Yoseph, 2009, Analisis Kebangkrutan metode Z-Score Altman, Springate dan Zmijewski pada PT. Indofood Sukses Makmur Tbk Periode 2005 - 2009, Universitas Kristen Maranatha

Platt, H.D. \& Platt, M.B. 1990, Development of a Class of Stable Predictive Variables: The Case of Bankruptcy Predictions. Journal of Business Finance \& Accounting, 17: 31-51

Platt, H., dan M. B. Platt. 2002, Predicting Financial Distress, Journal of Financial Service Professionals.

Pramudtya Yudha Andhika. 2014, Analisis Penerapann Mekanisme Corporate Governance Terhadap Kemungkinan Perusahaan Mengalami Financial Distress, Universitas Diponegoro, Semarang

Prihadi, Toto. 2011. Analisis Laporan Keuangan Teori dan Aplikasi Jakarta: PPM

Sartono, Agus. 2001, Manajemen Keuangan (Teori dan Aplikasi), Edisi Keempat. Yogyakarta:BPFE 
Sharpe, W.F, dkk, 1999, Investasi, alih bahasa Henri N dan Agustian, Prendhalindo, Jakarta.

Sjahrial, Dermawan. 2014, Manajemen Keuangan Lanjutan, Edisi revisi Jakarta:Mitra Wacana Media

Suad,Husan \&,Enny Pudjiastuti. 2012, Dasar-dasar Manajemen Keuangan. Yogyakarta: UPP STIM YKPN Sujawerni,Wiratna.V. 2015, SPPS Untuk Penelitian, Yogyakarta: Pustaka Baru Press

Tandelilin,E., 2001, Analisis Investsi dan Manajemen Portofolio, Edisi Pertama, Penerbit BPFE, Yogyakarta.

Tandelilin,E., \& I Wayan Nuka Lantara, 2001, Stabilitas dan Prediktabilitas Beta Saham: Studi Empiris di Bursa Efek Jakarta, Jurnal Ekonomi dan Bisnis Indonesia.

Zmijewski, M.E. 1984, Methodological Issues Related to the Estimation of Financial Distress Prediction Models. Journal of Accounting Research, 22: 59-82. 